\title{
1. Regionalism and refugee protection
}

This book examines a number of different multilateral arrangements for refugees, all of which have been described as 'regional' arrangements in the literature. But are they truly regional, and do regional approaches offer something additional to or better than the universal framework for refugees? It is not immediately obvious why a regional approach should be adopted. Are refugees merely a regional problem and what role does 'regionalism' play in responding to the global issue of refugees? What does the term 'regionalism' signify, other than a geographical reference point? What might regional arrangements offer that is better than or supplemental to a global approach? And, most importantly for our purposes, how does regionalism promote or impede the protection of refugees and responsibility-sharing?

Frequently recurring features of many arrangements regarding refugees suggest that the term 'regional' is appropriate as a descriptor. The origin and impact of the refugee flow concerned may be largely confined to a particular geographical region of the globe; states in this region may participate in the arrangement; and the arrangement may be adopted under, or may otherwise involve a regional organization such as the European Union, the African Union or the Organization of American States.

On the other hand, some arrangements involve states from all parts of the world. States from outside the region in which the refugee flow begins may play important roles in providing durable solutions for refugees such as resettlement or financial support. Seventy-five countries were represented at the conference at which the Comprehensive Plan of Action for Indochinese Refugees (CPA) was adopted in 1989. Crucially, the CPA secured the participation of Australia, Belgium, Canada, Denmark, Finland, France, Germany, Japan, the Netherlands, New Zealand, Norway, Sweden, Switzerland, the United Kingdom and the United States in resettlement. ${ }^{1}$ Even the Common European Asylum System (CEAS), which has been adopted under EU auspices and is limited to EU

1 W C Robinson, Terms of Refuge: The Indochinese Exodus \& the International Response (Zed Books, 1998) Appendix 2. 
members, with some participation by associated states, Norway, Liechtenstein, Iceland and Switzerland, ${ }^{2}$ has an external element. The external element includes a joint EU resettlement programme and five regional protection programmes which are primarily focussed on protection and durable solutions within countries of first asylum. ${ }^{3}$

In this chapter, we look first at regionalism as a phenomenon in international politics. Second, we consider the history of regionalism in refugee law. Third, we look at five main regions of the world, examining 'regionalism' and the approach to asylum in those areas as context for our examination of regional arrangements. Finally, we examine possible reasons to promote regional arrangements for sharing refugees and potential downsides of regional approaches.

\section{REGIONALISM IN INTERNATIONAL POLITICS}

Regions and regionalism, Louise Fawcett explains, are contested and often fuzzy concepts. ${ }^{4}$ What defines a region is not simply a matter of geography, but may include identifiable patterns of behaviour, an imagined community, ${ }^{5}$ or a geographical relationship and a degree of mutual interdependence. ${ }^{6}$ Meanwhile, regionalism aims to "pursue and promote common goals in one or more issue areas'7 on a 'geographically restricted basis'. 8 Regionalism can manifest as 'hard regionalism' institutional organizations, for example - or 'soft regionalism' that fosters

2 See Steve Peers, The Second Phase of the Common European Asylum System: A Brave New World - or Lipstick on a Pig? (Statewatch, 2013) $<$ http://www.statewatch.org/analyses/no-220-ceas-second-phase.pdf>. As Peers has noted, the UK, Ireland and Denmark have opted out of the second phase of the Common European Asylum System.

3 The five regional protection programmes are for the Great Lakes Region (focused on Tanzania), the Western Newly Independent States (Belarus, Moldova and Ukraine), the Horn of Africa (Kenya, Djibouti and Yemen), Eastern North Africa (Tunisia, Libya and Egypt) and the Middle East (Lebanon, Jordan and Iraq), the last of which, a 'regional development and protection programme' is a response to the Syrian refugee crisis.

4 Louise Fawcett, 'Exploring Regional Domains: A Comparative History of Regionalism' (2004) 80(3) International Affairs 429, 431.

5 This idea draws on Benedict Anderson, Imagined Communities: Reflections on the Origin and Spread of Nationalism (Verso, 1983).

6 Fawcett, above n 4, 432.

7 Ibid 433.

8 John Ravenhill, APEC and the Construction of Pacific Rim Regionalism (Cambridge University Press, 2001) 6. 
a sense of community. ${ }^{9}$ It is not confined to states and Fawcett argues that 'a truly successful regionalist project today presupposes eventually linkages between state and non-state actors: an interlocking network of regional governance structures, such as those already found in Europe, and to some extent in the Americas, as demonstrated in the NAFTA process'.10

Many purposes may be, or have been pursued through regionalism, such as cooperation, whether in the pursuit of an imagined regional community or not, gaining economies of scale otherwise unavailable to small states wanting to be competitive, containment of a hegemon, and so on; and there are various theoretical explanations of regionalism, particularly regional integration. For example, neofunctionalism posits that states integrate in order to secure maximum welfare, while intergovernmentalism views regional integration as a series of bargains by political leaders. ${ }^{11}$ As Ravenhill points out, theories of regionalism are often mutually contradictory, ${ }^{12}$ and there may be "more angst than joy in theorizing about regionalism.' 13

The possibilities of regionalism and the forms it takes depend on factors such as levels of interdependence and shared identity in the region. ${ }^{14}$ Fawcett flags three issues as highly important: capacity, sovereignty and hegemony. ${ }^{15}$ As she says, lack of capacity as well as concerns about sovereignty may mean that some regional institutions are mere talking shops. ${ }^{16}$ Meanwhile strong states are able to use regional groups as a cover for their own interests. ${ }^{17}$ Conversely, however, regional groups may contain the power of the regional hegemon. ${ }^{18}$

Immediately after the Second World War, universal multilateral institutions were emphasized - the formation of the United Nations being the key example - but, as Hurrell writes, regionalism became more important because of the Cold War impact on the universal institutions. Well-known Cold War problems at the UN include the infamous deadlock of the UN

\footnotetext{
9 Fawcett, above n 4, 433.

10 Ibid 433.

11 Walter Mattli, The Logic of Regional Integration: Europe and Beyond (Cambridge University Press, 1999) 10.

12 Ravenhill, above n 8, 9.

13 Ibid 38.

14 Fawcett, above n 4, 435.

15 Ibid 442.

16 Ibid 443.

17 Ibid 444.

18 Ibid 445. Examples include the United States in the Americas, and Russia and Uzbekistan in Central Asia.
} 
Security Council and the slow progress of translation of human rights into the two major treaties - the International Covenant on Civil and Political Rights and the International Covenant on Economic, Social and Cultural Rights. ${ }^{19}$ Regionalism 'gathered pace' in the late 1980s, leading to much scholarship on the 'new regionalism'. ${ }^{20}$

The 'old' regionalism or the first wave that emerged in Europe in the late 1940s and led to institutional structures such as the European Economic Community was focused on integration and, as described by Söderbaum and Shaw, "had its roots in the devastating experience of inter-war nationalism and the Second World War.' ${ }^{21}$ The key debate about the old regionalism was 'whether regionalization was a stumbling-block or a stepping-stone towards globalization and improved multilateralism.' ${ }^{22}$

'New' regionalism is not necessarily focused on supra-national institutions, ${ }^{23}$ though there are examples of the latter in recent times - for example, the creation of the African Union which, similarly to the EU, it is hoped, will promote peace and prosperity in the African continent through integration. ${ }^{24} \mathrm{~A}$ lot of new regionalism has focused on the neo-liberal agenda of opening up economies to the global market. 25 There is, however, a critical scholarship of 'new regional approaches' which focuses on other forms of regionalism, such as bottom-up regionalism effected by non-state actors. ${ }^{26}$

19 International Covenant on Civil and Political Rights, opened for signature 16 December 1966, 999 UNTS 171 (entered into force 23 March 1976); International Covenant on Economic, Social and Cultural Rights, opened for signature 16 December 1966, 993 UNTS 3 (entered into force 3 January 1976).

20 Andrew Hurrell, 'One World? Many Worlds? The Place of Regions in the Study of International Society’ (2007) 83(1) International Affairs 127, 129.

21 Timothy M Shaw and Fredrik Söderbaum, 'Introduction: Theories of New Regionalism' in Timothy M Shaw and Fredrik Söderbaum (eds), Theories of New Regionalism: A Palgrave Reader (Palgrave Macmillan, 2003) 1, 3.

22 Ibid 5.

23 J Andrew Grant and Fredrik Söderbaum, 'Introduction' in J Andrew Grant and Fredrik Söderbaum (eds), The New Regionalism in Africa (Ashgate, 2003) 1, $3-5$.

24 For analysis, see Olufemi Babarinde, 'The EU as a Model for the African Union: the Limits of Imitation' (Jean Monnet/Robert Schuman Paper Series 7 (2), Miami-Florida European Union Center of Excellence, 2007) 3.

25 Grant and Söderbaum, above n 23, 8.

26 Ibid 9; Okechukwu C Iheduru, 'New Regionalism, States and Non-State Actors in West Africa' in J Andrew Grant and Fredrik Söderbaum (eds), The New Regionalism in Africa (Ashgate, 2003) 47. 
A final phenomenon worth noting is that of 'inter-regionalism' - put most simply, region-to-region interaction. ${ }^{27}$ This phenomenon could play a role in resolving refugee flows - for example, the flow from the Middle East and North Africa to Europe. Perhaps it might also be an appropriate descriptor for schemes that propose collaboration between the Global North and the Global South.

Despite the wealth of theoretical material seeking to explain regionalism as a phenomenon, there is, disappointingly, remarkably little discussion of refugee flows, or even migration more broadly in the literature concerning the new regionalism, although some refugee lawyers have acknowledged the impact of regionalism on refugee protection. ${ }^{28}$ Walter Mattli, a theorist of regionalism who does touch on migration, describes the way in which the prospect of economic migration, particularly unauthorized migration from poorer economies on the periphery of a regional union, may be handled by offering trade and investment to these states in an effort to deflect the possibility of migration. ${ }^{29}$ When the European Community (as it then was) was faced with mass migration from Eastern Europe, trade concessions were offered first in an effort to stop migration. ${ }^{30}$ The EU's regional protection programmes ${ }^{31}$ could similarly be viewed as an attempt at containment of refugee flows. ${ }^{32}$

In the past, however, regionalism has often been a force not for containment, but expansion in refugee protection, establishing and expanding basic norms. The next section undertakes a retrospective, underscoring the positive impact that regionalism has had for refugee protection.

27 For a good discussion of inter-regionalism and a critique of the terms 'old' and 'new' regionalism, see Fredrik Söderbaum and Luk Van Langenhove, 'Introduction: The EU as a Global Actor and the Role of Interregionalism' (2005) 27 Journal of European Integration 249.

28 Susan Kneebone and Felicity Rawlings-Sanaei (eds), New Regionalism and Asylum Seekers: Challenges Ahead (Berghahn Books, 2007); see also Ademola Abass and Francesca Ippolito (eds), Law and Migration: Regional Approaches to the Protection of Asylum Seekers: an International Legal Perspective (Ashgate, 2014).

29 Mattli, above n 11, 95.

30 Ibid 97-9.

31 See above n 3 and accompanying text.

32 For discussion of the history of the regional protection programmes and why some commentators see them as emanating from an impulse of migration control rather than a protection ethos, see Madeline Garlick, 'The EU Discussions on Extraterritorial Processing: Solution or Conundrum?' (2006) 18 International Journal of Refugee Law 601. 


\section{REGIONALISM AND REFUGEES IN HISTORICAL PERSPECTIVE}

Regional efforts to protect refugees have a long heritage. The major international treaty for the protection of refugees - the 1951 Convention Relating to the Status of Refugees ${ }^{33}$ which, together with its 1967 Protocol $^{34}$ now boasts 148 countries as parties - can itself be viewed as a regional document. ${ }^{35}$ It was conceived as a response to refugees in Europe displaced during the course of the Second World War and those fleeing Communist countries after the war. The definition of a refugee applies to someone who is outside their country of origin and unable or unwilling to return owing to a well-founded fear of being persecuted for reasons of race, religion, nationality, membership of a particular social group or political opinion ${ }^{36}$ - so it clearly captures the experiences of Jews fleeing the Nazis and responds by obliging states to provide protection.

The Refugee Convention imposes the obligation of non-refoulement ${ }^{37}$ - the obligation not to return a refugee to a country where the person apprehends, on good grounds, that he or she will be irreparably harmed. Those who drafted the Refugee Convention were clearly of the view that to return a refugee to the prospect of irreparable harm would implicate the authorities of the country in which asylum had been sought. To return a refugee, they said, would be tantamount to delivering him into the arms of his persecutors. ${ }^{38}$ In other words, we take responsibility for refugees in order to protect human dignity; if we do not, we are responsible for what eventually may befall them.

33 Convention Relating to the Status of Refugees, opened for signature 28 July 1951, 189 UNTS 150 (entered into force 22 April 1954) (Refugee Convention).

34 Protocol Relating to the Status of Refugees, opened for signature 31 January 1967, 606 UNTS 267 (entered into force 4 October 1967).

35 Susan Kneebone and Felicity Rawlings-Sanaei, 'Introduction: Regionalism as a Response to a Global Challenge' in Susan Kneebone and Felicity Rawlings-Sanaei (eds), New Regionalism and Asylum Seekers: Challenges Ahead (Berghahn Books, 2007) 4.

36 Refugee Convention, above n 33, Art 1A(2).

37 Ibid Art 33.

38 Report of the Ad Hoc Committee on Statelessness and Related Problems, (Lake Success, New York, 16 January - 16 February 1950) (UN Economic and Social Council, 17 February 1950) UN Doc E/1618; UN Doc E/AC.32/5 <http://www.refworld.org/docid/40aa15374.html> annex II (Comments on the Draft Convention). 
Any breach of the obligation of non-refoulement entails liability as a matter of international law. Importantly, the obligation extends to "chain refoulement' whereby a state sends a refugee to a third state which then returns the refugee to a place of persecution, and it applies extraterritorially, meaning that states cannot intercept refugees in places beyond their territory in order to return them to a place of persecution. ${ }^{39}$ The Refugee Convention also sets out a bill of rights for refugees, including rights to education (Article 22), to work (Articles 17, 18 and 19), freedom of religion (Article 4) and access to the courts (Article 16), as well as some rights that deal with particular refugee problems, such as a right to travel documents (Article 28). This compensates for the lack of protection from the state of origin.

In common with many areas of international law, the 'universal law' has reflected a particular European experience. ${ }^{40}$ This does not necessarily undermine the importance of the universal norms established - in the case of refugee law, the norm of non-refoulement - given the widespread practice in conformity with it (discussed below) and the diverse religious and philosophical traditions that also support it (discussed in Chapter 2). However, the historically contingent nature of what has become universal law does remind us to question the interests reflected in the law, a particularly pertinent inquiry when considering the way in which responsibility for refugee protection is or is not shared amongst members of the international community.

39 Concerning extra-territoriality of non-refoulement, see Haitian Center for Human Rights $v$ United States of America (Inter-American Commission of Human Rights, Case 10.675, Report No 51/96, 13 March 1997) [156]-[158]. The extra-territoriality of the prohibition on torture and related ill-harm in the European Convention on Human Rights has been confirmed by the European Court of Human Rights in Hirsi Jamaa and Others v Italy (European Court of Human Rights, Grand Chamber, Application No 27765/09, 23 February 2012). The prohibition on chain refoulement has been confirmed in M.S.S. v Belgium and Greece (European Court of Human Rights, Grand Chamber, Application No 30696/09, 21 January 2011).

40 For analyses of international law's tendency to universalize from European perspectives and experiences, see Anthony Anghie, Imperialism, Sovereignty and the Making of International Law (Cambridge University Press, 2004); Sundhya Pahuja, Decolonizing International Law: Development, Economic Growth and the Politics of Universality (Cambridge University Press, 2011). 


\section{The Universalization of the Refugee Convention}

Since the Refugee Convention was adopted back in 1951, many other human rights treaties have extended the obligation of non-refoulement to other forms of harm, including torture ${ }^{41}$ and forced disappearance. ${ }^{42}$ Even in states that have not signed up to these treaty obligations, it would be rare indeed to find a statesperson who would argue that it is permissible to return someone to these forms of harm. International lawyers argue that there is now an unwritten norm of international law a customary international law - forbidding refoulement to torture and persecution.

Traditionally, the development of customary international law requires widespread and consistent ${ }^{43}$ state 'practice' (that is, what states actually do), combined with a belief that the practice is required by law (the element known as opinio juris). Opinio juris may be gleaned from statements by state officials - for example, in diplomatic correspondence or statements justifying a vote for a resolution on the floor of the United Nations' General Assembly. Customary international law has a particularly slippery handle because of the lack of adjudication in the international legal system. States may do things they are not supposed to do and which may be prohibited by treaty, including the United Nations Charter $^{44}$ itself, with relative impunity. In the case of human rights treaties, which may be honoured in the breach when states that violate them deny the violation or seek to justify it in some way, participation in the treaties themselves tends to be treated as the relevant practice, and

41 Convention against Torture and Other Cruel, Inhuman or Degrading Treatment or Punishment, opened for signature 10 December 1984, 1465 UNTS 85 (entered into force 26 June 1987).

42 International Convention for the Protection of All Persons from Enforced Disappearance, opened for signature 20 December 2006, UNTS 2715 (entered into force 23 December 2010).

43 See for example the test set in the Asylum Case of 'constant and uniform' practice: Asylum Case (Colombia v Peru) [1950] ICJ Reports 266 [279].

44 This was the dilemma faced by the International Court of Justice in the famous Nicaragua case where it had to ascertain the customary international legal rules relating to the use of force in international relations in the face of several breaches of the UN Charter, because the Charter was ousted from consideration as a result of the United States' reservations to the Court's jurisdiction: Military and Paramilitary Activities In and Against Nicaragua (Nicaragua v United States of America) (Merits) [1986] ICJ Rep 14. 
certainly not the violations of human rights. ${ }^{45}$ It is accepted that widely ratified treaties can codify customary international law, crystallize inchoate norms of customary international law or generate new customary international law. ${ }^{46}$

It is well-accepted that the prohibition on torture and related illtreatment and its ban on refoulement to a place where these forms of ill-treatment will occur is customary international law, and, moreover, jus cogens, meaning that it is non-derogable in all circumstances and binding on every single state. This is despite the frequency with which torture is carried out. ${ }^{47}$ It is also widely accepted that the prohibition on refoulement to a place of persecution is customary international law. ${ }^{48}$ In 2001 , the parties to the Convention and to the Protocol declared that the obligation of non-refoulement contained in the 1951 Convention Relating to the Status of Refugees is customary international law. ${ }^{49}$

Many states that are not party to the universal instruments on refugee protection or their regional counterparts have in practice accepted an obligation of temporary refuge with respect to refugees. However, some states may resist entirely the idea that they are bound not to return refugees as a matter of international law. Sri Lanka, for example, has

45 Anthea Roberts, 'Traditional and Modern Approaches to Customary International Law' (2001) 95 American Journal of International Law 757.

46 For the principle that widely ratified treaties may generate customary international law, see North Sea Continental Shelf Cases (Federal Republic of Germany v Denmark; Federal Republic of Germany v Netherlands) (Judgment) [1969] ICJ Rep 3.

47 Until the 'war on terror' it would have been possible to assert that surely no state official would ever argue that these forms of ill-treatment were justified. Infamously, the so-called 'torture memos' developed by the United States State Department do argue that ill-treatment is justified in certain circumstances. See Karen J Greenberg and Joshua L Dratel, The Torture Papers: The Road to Abu Ghraib (Cambridge University Press, 2005) 172, 213-4. The Obama administration voided most of these memos through Executive Order EO 13492 'Ensuring Lawful Interrogation' (signed 22 January 2009) 74 FR 4893, 27 January 2009. In any event, the arguments in the torture memos are not accepted by the majority of international legal opinion.

48 Elihu Lauterpacht and Daniel Bethlehem, 'The Scope and Content of the Principle of Non-Refoulement: Opinion' in Erika Feller, Volker Türk and Frances Nicholson (eds), Refugee Protection in International Law: Global Consultations on International Protection (Cambridge University Press, 2003) 87, 149.

49 Declaration of States Parties to the 1951 Convention and or Its 1967 Protocol Relating to the Status of Refugees (adopted at the Ministerial Meeting of States Parties in Geneva Switzerland on 13 December 2001) UN Doc HCR/MMSP/2001/09 (16 January 2002) [4]. 
been strident in its opposition to protection of refugees, particularly Tamils seeking protection in other countries. ${ }^{50}$ It is also notable that in the case of the Southeast Asian states that participated in the Comprehensive Plan of Action for Indochinese refugees, ${ }^{51}$ agreement to accord temporary refuge or first asylum was premised on the acceptance of resettlement obligations by Western states. Some of the Southeast Asian states pushed back boats, meaning that they might argue they are 'persistent objectors' to the prohibition on refoulement and therefore not bound by the customary international legal prohibition of nonrefoulement. ${ }^{52}$ Thailand has pushed back boats of Rohingya ${ }^{53}$ and later Malaysia and Indonesia also threatened not to accept Bangladeshi migrants and Rohingya asylum seekers. ${ }^{54}$ On the other hand, Thailand is a member of the Executive Committee of the High Commissioner's Programme (ExCom), which has constantly reaffirmed non-refoulement as customary international law. ${ }^{55}$ Furthermore, the ASEAN Human Rights Declaration now protects a right to seek and receive asylum, although a 'clawback' clause that refers to applicable international agreements and the law of the state concerned needs to be read down in order to make the provision meaningful. ${ }^{56}$

50 See for example the first report by Sri Lanka to the UN CounterTerrorism Committee, where Sri Lanka stated it did not grant asylum as a matter of policy: First Report of Sri Lanka UN Doc S/2001/1282 (27 December 2001) 6 .

51 UN General Assembly, Declaration and Comprehensive Plan of Action of the International Conference on Indo-Chinese Refugees, Report of the SecretaryGeneral UN DocA/44/523 (22 September 1989) <www.unhcr.org/refworld/ docid/3dda17d84.html $>$.

52 The principle of the persistent objector was accepted by the International Court of Justice in the Anglo-Norwegian Fisheries Case: Fisheries Case (United Kingdom v Norway) (Judgment) [1951] ICJ Rep 116 [138]-[139].

53 Human Rights Watch, 'Thailand: Fleeing Rohingya Shot in Sea by Navy', Human Rights Watch (online), 13 March 2013 <http://www.hrw.org/news/2013/ 03/13/thailand-fleeing-rohingya-shot-sea-navy>.

54 'Malaysia to follow Indonesia in turning back migrant boats; thousands may face starvation at sea', $A B C$ News (online), 13 May $2015<\mathrm{http}: / / \mathrm{www}$. abc.net.au/news/2015-05-13/malaysia-to-turn-back-migrant-boats/6466726>.

55 Walter Kälin, Martina Caroni and Lukas Heim, 'Article 33, Para. 1' in Andreas Zimmermann (ed), The 1951 Convention Relating to the Status of Refugees and its 1967 Protocol: a Commentary (Oxford University Press, 2011) $1327,1345$.

56 ASEAN Human Rights Declaration (adopted by the Heads of State/ Government of ASEAN Member States at Phnom Penh, Cambodia, 18 November 2012). 
It is possible to conclude that despite the contrary practice by some states parties and the non-accessions by some other states, the Refugee Convention has acted as an important precedent, establishing the universal principle that there are some situations to which we will never return a person because to do so would be complicit in the harm that follows.

\section{Regional Reactions and Refinements to the Refugee Convention}

Despite its universal significance, the Refugee Convention's origins in regional history were quite obvious when it was first adopted. The Convention originally contained a deadline of 1 January 1951 and parties could choose to limit their obligations to refugees fleeing events in Europe; ${ }^{57}$ so it was both based on and limited to the European experience during the Second World War and its aftermath. These geographical and temporal limitations were lifted by the 1967 Protocol Relating to the Status of Refugees, ${ }^{58}$ which was itself responding to regional developments.

African countries were concerned by the narrow terms of the Convention definition, including the operation of the date line, ${ }^{59}$ and adopted their own refugee definition. Importantly, the definition adopted by the Organization of African Unity (OAU, now the African Union) includes refugees fleeing generalized violence, as well as those fleeing persecution for reasons connected to the five established grounds. ${ }^{60}$

57 Refugee Convention, above n 33, Art 1A(2) and Art 1B.

58 Protocol Relating to the Status of Refugees, above n 34. See Terje Einarsen, 'Drafting History of the 1951 Convention and the 1967 Protocol' in Andreas Zimmermann (ed), The 1951 Convention Relating to the Status of Refugees and its 1967 Protocol: A Commentary (Oxford University Press, 2011) 37, 69-70, 72 .

59 Chaloka Beyani, Protection of the Right to Seek and Obtain Asylum Under the African Human Rights System (Martinus Nijhoff, 2013) 8-9. For a critical view on the history of the African Convention, which underscores not the issue of persecution, but the date line, and the original concerns of some states with subversive activities by African freedom-fighters, see George Okoth-Obbo, 'Thirty Years On: A Legal Review of the 1969 OAU Refugee Convention Governing the Specific Aspects of Refugee Problems in Africa' (2001) 20(1) Refugee Survey Quarterly 79, 109-12.

60 Organization of African Unity Convention Governing the Specific Aspects of Refugee Problems in Africa, opened for signature 10 September 1969, 1001 UNTS 45 (entered into force 20 June 1974) <http://www.unhcr.org/45dc 1a682.html> ('OAU Convention') Art I(1) and (2). 
Since this development in Africa, other regions have also adopted expanded refugee definitions or extended a form of protection complementary to refugee status to those persons who do not fear persecution on one of the five grounds, but who still require protection from some irreparable harm. In Latin America, the Cartagena Declaration on Refugees $^{61}$ also extends protection to refugees fleeing generalized violence, ${ }^{62}$ and many states in that region have incorporated the expanded Cartagena definition into their national law. In Europe, a status known as subsidiary status is afforded to people fleeing generalized violence, ${ }^{63}$ although it is a fairly complex definition that continues to generate controversy about its precise ambit. ${ }^{64}$ In our view, it would be highly desirable for the broader definitions of refugees or beneficiaries of refugee-like protection (minus the problematic wording contained in the European definition) to become universal norms. Responsibility-sharing between regions is hampered by insistence on the narrow definition contained in the Refugee Convention.

In two other regions, Asia and the Pacific, and the Middle East, although customary international law applies, there are many states which are not party to the universal instruments and there is also precious little by way of regional refugee law. In the Asian region, there are the Bangkok Principles on Status and Treatment of Refugees adopted by an

61 Cartagena Declaration on Refugees (adopted by the Colloquium on the International Protection of Refugees in Central America, Mexico and Panama, 22 November 1984) in 'Annual Report of the Inter-American Commission on Human Rights' (1984-85) OAS Doc OEA/Ser.L/V/II.66/doc.10, rev 1, 190-3.

62 The Cartagena Declaration states that the definition or concept of a refugee to be recommended for use in the region is one which, in addition to containing the elements of the 1951 Convention and the 1967 Protocol, includes among refugees persons who have fled their country because their lives, safety or freedom have been threatened by generalized violence, foreign aggression, internal conflicts, massive violation of human rights or other circumstances which have seriously disturbed public order' (ibid III(3)).

63 Council Directive 2011/95/EU of 13 December 2011 on Standards for the Qualification of Third-Country Nationals or Stateless Persons as Beneficiaries of International Protection, for a Uniform Status for Refugees or for Persons Eligible for Subsidiary Protection, and for the Content of the Protection Granted [2011] OJ L 337/9 ('Recast Qualification Directive').

64 Francesca Ippolito, 'Establishing the Common European Asylum System: It's a long way to Tipperary' in Abass and Ippolito (eds), Regional Approaches to the Protection of Asylum Seekers: An International Legal Perspective (Ashgrove, 2014) $113,121$. 
advisory body, the Asian-African Legal Consultative Organization. ${ }^{65}$ However, this instrument does not appear to have been widely implemented in national laws in the region. The reasonably new ASEAN Human Rights Declaration ${ }^{66}$ also recognizes the right to seek and receive asylum, but it is not binding. In the Middle East there is an Arab Convention on Regulating Status of Refugees in the Arab Countries, ${ }^{67}$ but it is not in force, and, as with the Asia-Pacific region, we find many countries do not have national laws and procedures for the protection of refugees. On the other hand, refugees are in practice tolerated in those regions and non-refoulement is widely, if imperfectly, respected.

\section{THE FIVE MAJOR REGIONS OF THE WORLD: AN OVERVIEW}

Thus far, the chapter has examined the development of the universal instruments on refugee protection and regional counterparts. We now look at the five major regions of the globe, the nature of the refugee flows within those regions, and regional structures, including regional architecture for reception and protection of asylum seekers. This provides vital context for the regional arrangements examined later in this book.

\section{Europe}

Europe may be regarded as the birthplace of the modern universal refugee protection instruments, and the definition of a refugee contained in the Refugee Convention has often been described as Eurocentric. ${ }^{68}$ Interestingly, though, European countries looked outwards to other countries to share responsibility for refugees, although the drafters could not

65 Final Text of the AALCO's 1966 Bangkok Principles on Status and Treatment of Refugees (adopted by the Asian-African Legal Consultative Organization in New Delhi, 40th sess, 24 June 2001).

66 ASEAN Human Rights Declaration, above n 56.

67 Arab Convention on Regulating Status of Refugees in the Arab Countries (adopted by the League of Arab States, 1994) <http://www.refworld.org/docid/ 4dd5123f2.html>.

68 See, for example, Sara E Davies, 'The Asian Rejection?: International Refugee Law in Asia' (2006) 52 Australian Journal of Politics and History 562, 570. Davies analyses the drafting history of the Convention and Protocol and shows that the concerns of India and Pakistan were not dealt with by the drafters of the Convention. 
agree to a binding burden-sharing obligation. ${ }^{69}$ For example, Australia, although it perceived itself as European or at least British at the time, was geographically far removed from the European theatre of war. Yet it participated in the conference of plenipotentiaries which adopted the final text of the Convention and it was the sixth country to become party. Indeed, it was Australia's accession to the treaty that brought it into force.

Regionalism is well-entrenched in Europe, and continues to have an impact on refugee protection. Two regional structures, the Council of Europe and the European Union (EU), incorporate human rights and refugee protection standards. The EU is probably the most successful example of regional integration in the world. It began with economic integration, although this was clearly linked to security, while the Council of Europe was envisaged as an organization that would promote human rights and democracy in Europe.

69 The secretariat's draft contained a chapter on admission with one article that said favourable consideration should be given to asylum seekers and that the parties 'shall to the fullest possible extent relieve the burden assumed by initial reception countries which have afforded asylum ... They shall do so, inter alia, by agreeing to receive a certain number of refugees in their territory.' The commentary on the draft article acknowledges the inequitable allocation of responsibility for refugee protection imposed by the vagaries of geographical location. See Memorandum by the Secretary-General for the Ad Hoc Committee on Statelessness and Related Problems, Status of Refugees and Stateless Persons, E/AC.32/2 (3 January 1950). In the ensuing discussion by the committee members, those delegates who described themselves as 'initial countries of reception' (we would use the term 'countries of first asylum' today) spoke in favour of such a provision on the basis that they hoped other states parties would admit refugees in order to share the 'burden' of hosting refugees: UN Ad Hoc Committee on Refugees and Stateless Persons, Ad Hoc Committee on Refugees and Stateless Persons, Second Session: Summary Record of the Thirty-Seventh Meeting Held at the Palais des Nations, Geneva, on Wednesday, 16 August 1950, at 3.00 p.m., UN Doc E/AC.32/SR.37 (26 September 1950) 2-13. As this provision was voted down, the Chair noted that there would need to be another place found for it - for example, in the preamble (ibid 13). One of the proponents of the defeated provision concerning admission, France, introduced a preambular paragraph into debate at the ECOSOC Social Committee, which was objected to by other states, perceiving an implicit obligation of admission and it was rejected: Ralf Alleweldt, 'Preamble 1951 Convention' in Andreas Zimmermann (ed), The 1951 Convention Relating to the Status of Refugees and its 1967 Protocol: A Commentary (Oxford, 2011) 225, 236-7. However, France persisted and the preamble does refer to the need for international cooperation given the 'heavy burdens on certain countries'. 
The Council of Europe is composed of 47 member states, all of which are party to the European Convention on Human Rights (ECHR). ${ }^{70}$ While the European Court of Human Rights (ECtHR) cannot rule directly on the Refugee Convention, it can rule on rights of refugees under the ECHR, including, most importantly, the prohibition on refoulement to a place of torture or inhuman or degrading treatment or punishment which is implied into Article 3 of the ECHR. The Court has decided many important cases of this nature, some of which are referred to in this book.

The EU is the other relevant set of regional institutional arrangements. It numbers 28 members. The EU is required to accede to the ECHR and negotiations for this to occur are ongoing. ${ }^{71}$ The EU has also adopted the Charter of Fundamental Rights of the European Union, ${ }^{72}$ which protects against torture or inhuman or degrading treatment or punishment in Article 4.

All members of the EU are party to the Refugee Convention and Protocol, and the EU has adopted several instruments that seek to establish a Common European Asylum System (CEAS). ${ }^{73}$ The Court of Justice of the EU is able to enforce the instruments comprising the CEAS, meaning that, to the extent these instruments conform to the Refugee Convention's standards, there is an active system for enforcing the Convention.

Since the Second World War, when Europe's refugees were all Europeans, there have been major intra-regional refugee crises, with the implosion of the former Yugoslavia (which was an Eastern European

70 European Convention for the Protection of Human Rights and Fundamental Freedoms, opened for signature 4 November 1950, ETS 5 (entered into force 4 January 1969).

71 The Court of Justice of the European Union declared the draft agreement for accession to be incompatible with EU law in December 2014: Opinion 2/13(2014) EU:C:2014:2425. However, the Commission remains committed to the goal of accession.

72 Charter of Fundamental Rights of the European Union [2010] OJ C $83 / 02$.

73 Recast Qualification Directive, above n 63; Council Directive 2013/33/EU of the European Parliament and Council of 26 June 2013 Laying Down Standards for the Reception of Applicants for International Protection [2013] OJ L 180/96 ('Recast Reception Directive'); Regulation (EU) No 604/2013 of the European Parliament and of the Council of 26 June 2013 establishing the criteria and mechanisms for determining the Member State responsible for examining an application for international protection lodged in one of the Member States by a third-country national or a stateless person (recast) [2013] OJ L 180/31 ('The Dublin III Regulation'). 
country and not a member of either the Council of Europe or the European Community), subsequent conflicts in Bosnia and Kosovo and, beginning in 2014, conflict in Ukraine. However, the focus of the CEAS is extra-regional refugees. All the relevant instruments are limited to 'third country nationals', that is, citizens of non-EU states. It is assumed that all EU countries are safe countries of origin, which is demonstrably untrue. Roma, who are theoretically EU citizens, face many forms of discrimination and even persecution. ${ }^{74}$ Theoretically, EU citizens could just exercise their freedom of movement rights within the EU to escape persecution, but in addition to the many barriers to Roma exercising those freedoms, there have been disturbing mass expulsions of Roma from a number of EU states, which highlights the importance of refugee status for those Roma facing persecution. ${ }^{75}$

It is also assumed that all EU countries are safe for refugees fleeing from non-EU member states, and the basic principle is that the first state entered by an unauthorized refugee is the state responsible for determining refugee status and providing protection. ${ }^{76}$ The impact of this rule for responsibility-sharing is returned to in Chapter 7. The assumption of safety has been demonstrated to be false in the course of litigation. ${ }^{77}$

The focus on extra-regional refugees is not surprising given the EU's focus on policing its 'external' borders while bringing down barriers to the internal movement of the citizens and long-term residents of EU states. It is widely believed that a reason for soaring asylum applications in the early 1990s, particularly in Germany, is that legal channels of migration were tightened during the recession so that many asylum seekers were in fact economic migrants. ${ }^{78}$ As will be seen in the detailed discussion of the CEAS and the external aspects of European asylum policy in Chapter 7, Europe has made only small steps towards equitable

74 See, for example, the decision of the Irish High Court that denial of basic primary education to a Roma child from Serbia (which at the time of writing this book was not a member of the EU) was persecution: $D$ (a minor) $v$ Refugee Appeals Tribunal [2011] IEHC 431.

75 For analysis of the legal issues concerning migration and Roma, see Claude Cahn and Elspeth Guild, Recent Migration of Roma in Europe (Organization for Security and Cooperation in Europe, 2nd ed, October 2010).

76 Dublin III Regulation, above n 73, Art 13.

77 M.S.S. v Belgium and Greece, above n 39; N. S. v Secretary of State for the Home Department and M. E. and others v Refugee Applications Commissioner, Minister for Justice, Equality and Law Reform (Court of Justice of the European Union, C-411/10 and C-493/10, 21 December 2011).

78 Matthew J Gibney, The Ethics and Politics of Asylum: Liberal Democracy and the Response to Refugees (Cambridge University Press, 2004) 95-6. 
arrangements to share responsibility for refugees who do not manage to present themselves at the borders of the EU or elude border control. However, the increase in boats of migrants and asylum seekers crossing the Mediterranean has prompted both proposals for a quota system (which were eventually adopted with respect to relocation of 120000 asylum seekers from Italy, Greece and Hungary to other parts of Europe) and for enforcement action authorized by the UN Security Council that would focus on destroying boats prior to departure from Libya (and a Council Resolution authorizing action on the High Seas was eventually adopted).

\section{Americas}

The Americas are home to the oldest of regional organizations, the Organization of American States (OAS), ${ }^{79}$ under the auspices of which a thriving regional human rights system has developed. The inauguration of the OAS was driven by the ideal of pan-Americanism - indicative of a sense of imagined community in this region - which is attributed to the great liberator of the Americas, Simón Bolívar. ${ }^{80}$ There is, however, significant diversity within the Americas. Geographically, the Americas include Canada and the United States of America, but within the United Nations system, Canada and the USA belong to the 'Western European and Others bloc'. Latin America and the Caribbean are quite distinct from Canada and the USA and from each other. There is significant diversity within Latin America too, particularly given the numerous Indigenous peoples of the region, although there is arguably strong regional identity in terms of a largely common language (Spanish) and the Catholic religion. As in any region, perceived national interests and cultures have contributed to differing refugee policies. ${ }^{81}$

Despite the many challenges confronting the OAS, it has established a vibrant set of human rights instruments, beginning with the OAS Charter

79 Organization of American States, Charter of the Organization of American States (adopted at the Ninth International Conference of American States, Bogotá, Colombia, 30 April 1948).

80 Marie Arana, Bolívar: American Liberator (Simon and Schuster, 2013).

81 Elizabeth Ferris' work on the Central American refugee crisis of the late 1970s and 1980s draws attention to these important differences: Elizabeth G Ferris, The Central American Refugees (Praeger, 1987). 
itself, the American Declaration on the Rights and Duties of Man, ${ }^{82}$ and the establishment of the Inter-American Commission on Human Rights. This was followed by the American Convention on Human Rights, ${ }^{83}$ which established the Inter-American Court of Human Rights. Issues of refugee protection have arisen within the Inter-American human rights system, most recently in the decision by the inter-American Court in the case of the Pacheco Tineo family, the first time the Court has ruled on the inter-American human rights system's protections concerning applications for asylum and protection from refoulement. ${ }^{84}$

There is also a venerable history of political asylum in Latin America - that is, the discretionary grant of asylum to particular individuals. ${ }^{85}$ This tradition could be viewed as a safety valve for governmental systems that failed to respect human rights and diversity. ${ }^{86}$ While there has been a small extra-regional caseload of refugees in Latin America, including from Africa and Asia, ${ }^{87}$ which may increase in the future, refugee flows have mainly been intra-regional within Latin America as a result of conflicts involving deep political divides between left and right, and the difficulties in translating the theoretical commitment to rule of law into practice. Unfortunately, the most powerful state in the Americas,

82 American Declaration of the Rights and Duties of Man (approved by the Ninth International Conference of American States), 2 May 1948, OAS Res XXX.

831969 American Convention on Human Rights (entered into force 18 July 1978), OAS Doc EA/Ser.K/XVI/1.1.doc.65, Rev 1, Corr 1 of 7 January 1970.

84 The Court held that the expulsion of the family violated the right to seek and be granted asylum and the principle of non-refoulement in the American Convention on Human Rights, as well as the right to a fair hearing and to judicial protection (recourse to the judiciary). In addition, the Court found violations of the family's right to mental and moral integrity, and the rights of the family and the child: Pacheco Tineo Family v Bolivia [InterAmerican Court of Human Rights] (2013) Series C No 272 (25 November 2013).

85 See 1889 Montevideo Treaty on International Penal Law (adopted by the First South American Congress on Private International Law in Montevideo on 23 January 1889) OAS Doc OEA/Ser.X/1 34; 1954 Caracas Convention on Territorial Asylum, OAS Doc OEA/Ser.X/1 34 (entered into force 29 December 1954).

86 Mario Sznajder and Luis Roniger, The Politics of Exile in Latin America (Cambridge University Press, 2009) 8.

87 UNHCR, 'Refugee Protection and International Migration in the Americas: Trends, Protection Challenges and Responses' (Paper presented at the Regional Conference on Refugee Protection and International Migration in the Americas: Protection Considerations in the Context of Mixed Migration, San José, Costa Rica, 19-20 November 2009) 14-15. 
the United States, has frequently supported right-wing governments in the Americas, thus prolonging conflicts and refugee situations and, indeed, denying that victims of these conflicts are refugees. ${ }^{88}$

The most recent, large-scale intra-regional flow of refugees, the Colombian refugee crisis exemplifies the political divisions that have generated refugee flows in the Americas. As Gottwald explains, the Colombian conflict began as an ideological conflict in 1948 between Liberals and Communists, transformed into a civil war, and then a period of insurgency against the government by the FARC (Revolutionary Armed Forces of Colombia) and the ELN (National Liberation Army). ${ }^{89}$ Later, paramilitary forces were formed to protect civilians from guerilla activities, ${ }^{90}$ which secured their funding through the drug trade. ${ }^{91}$ During the 1990s, the paramilitaries sought territorial control and civilians became a military target, while forced displacement became a military tactic, ${ }^{92}$ resulting in flight across the borders into Venezuela, Panama and Ecuador. The Colombian conflict has resulted in over 3 million refugees; peace negotiations commenced in 2012 appear to have resulted in a deal in late 2015 , but the future is still uncertain. ${ }^{93}$

The common experience of being on the receiving end of political violence and exile in other countries has arguably resulted in a strong commitment in principle to international refugee law. As Chilean President, Michelle Bachelet has said,

Thousands of women and men had to leave our land and experienced the warmth and humanity of other countries. Today it is our turn to give because we are now a democratic, free and pluralist society, with good levels of employment, social peace and human development. Today we must extend our hands to those who need us. ${ }^{94}$

88 For an excellent analysis of the USA's role in the Central American refugee crisis during the 1970s and 1980s, see Elizabeth G Ferris, above n 81 .

89 Martin Gottwald, 'Protecting Colombian Refugees in the Andean Region: The Fight against Invisibility' (2004) 16 International Journal of Refugee Law 517, 519-20.

90 Ibid 520.

91 Ibid 521.

92 Ibid 522.

93 Annette Idler, 'Colombia's deal with the FARC could bring peace - or create a power vacuum', The Conversation, 6 October 2015.

94 UNHCR, 'Southern Latin America Opens its Arms to Asylum-Seekers', News Stories (online), 27 August 2009 <http://www.unhcr.org/4a969d716.html>. 
The modern commitment to asylum is reflected in the inter-American human rights instruments, in adherence to the Refugee Convention and Protocol and the adoption of an expanded definition of refugee status in the form of the Cartagena Declaration on Refugees which recognizes persons fleeing generalized violence as refugees. ${ }^{95}$ Of the 35 OAS members, only five (Cuba, Barbados, Grenada, Guyana and St Lucia) do not participate in the Refugee Convention or Protocol at all, while St Kitts and Nevis is a nominal participant, having acceded only to the Convention but not the Protocol. It is notable that most of these states are Caribbean island states, and Guyana is often viewed as part of the Caribbean rather than Latin America. Arguably, most Caribbean states lack the capacity for refugee protection on a significant scale. Although they are generally party to the Convention and/or Protocol, UNHCR is responsible for refugee status determination in many cases and must use its mandate 96 to resettle refugees from the Caribbean.

Although non-binding, the Cartagena Declaration has been translated into the national laws of 14 countries, ${ }^{97}$ and there is a periodic review process that has resulted in further regional arrangements to improve refugee protection, such as the Mexico Declaration and Plan of Action to Strengthen International Protection of Refugees in Latin America. ${ }^{98}$ These arrangements, and the degree to which they share responsibility for refugees within the region and the extent of engagement from states from the Global North, are discussed in Chapter 8.

95 Cartagena Declaration on Refugees, above n 61.

96 UNHCR's mandate stems from the Statute of the United Nations High Commissioner for Refugees, UNGA Res 428(V) (14 December 1950). The beneficiaries of UNHCR's mandate have gradually expanded over the years, but, as UNHCR is not a state and does not have a territory in which it can protect refugees, it must negotiate with states to secure protection and durable solutions in many situations. These situations include the case of countries that are not party to the Convention or Protocol and also situations in which countries do not implement the Convention or Protocol nationally, as in Caribbean states.

97 Argentina, Belize, Bolivia, Brazil, Chile, Colombia, El Salvador, Guatemala, Honduras, Mexico, Nicaragua, Paraguay, Peru and Uruguay. See Pacheco Tineo Family v Bolivia [InterAmerican Court of Human Rights] (2013) Series C No 272 (25 November 2013) para 141.

98 Mexico Declaration and Plan of Action to Strengthen International Protection of Refugees in Latin America (16 November 2004). 


\section{Africa}

Africa's recent history is the history of colonialism and its aftermath. The key regional organization, the OAU (now the African Union) was conceived in the 1960s at the height of the decolonization movement. As pan-Africanism in the twentieth century focused on decolonization, its legacy was a commitment to sovereignty that resisted regionalism in the sense of integration. ${ }^{99}$ Thus, the OAU was not conceived of as a vehicle for integration. Yet at the same time, African sovereignty has been weak in the face of external forces. As Shaw writes, by the mid 1990s, 'Africa's political economy and political culture were quite transformed: from economic and political colonies, to political without economic independence, and then economic "liberalization" with an increasing range of political conditionalities'. ${ }^{100}$ In the 1990s, the end of the decolonization project and ongoing armed conflicts and human rights violations stimulated new thinking, evidenced by the transformation of the OAU into the African Union in 2002. ${ }^{101}$

While the OAU's record with respect to resolution of conflict was not impressive, it did oversee the establishment of a regional human rights system. The African (Banjul) Charter on Human and Peoples' Rights ${ }^{102}$ contains a right to 'seek and obtain asylum', ${ }^{103}$ as well as many other rights that serve to protect refugees. ${ }^{104}$ It is supervised by a Commission and a Court, and a flourishing and progressive jurisprudence has been

99 Daniel Bach, 'The Global Politics of Regionalism: Africa' in Mary Farrell, Björn Hettne and Luk Van Langenhove (eds), Global Politics of Regionalism: Theory and Practice (Pluto Press, 2005) 171.

100 Timothy M Shaw, 'Africa in the Global Political Economy: Globalization, Regionalization, or Marginalization?' in Björn Hettne, Andras Inotai and Osvaldo Sunkel (eds), The New Regionalism and the Future of Security and Development (Palgrave Macmillan/UNU/WIDER, 2000) 93, 94.

101 Bach, above n 99, 175.

102 African (Banjul) Charter on Human and Peoples' Rights, adopted 27 June 1981, OAU Doc. CAB/LEG/67/3 rev. 5, 21 I.L.M. 58 (entered into force 21 October 1986) ('Banjul Charter').

103 Ibid Art 12(3).

104 For discussion, see Gino J Naldi and Christiano d'Orsi, 'The Role of the African Human Rights System with Reference to Asylum Seekers' in Abass and Ippolito (eds), Regional Approaches to the Protection of Asylum Seekers: An International Legal Perspective (Ashgate, 2014) 45. 
established. Other organs of the African Union have also devoted some attention to refugee issues, but these have not been particularly effective. ${ }^{105}$

The state with the largest economy in the region, South Africa, is now a consistently high-volume asylum state, with many claimants coming from outside the region (for example, from Bangladesh) and, of course, African refugees and migrants have embarked on dangerous journeys to the West, most visibly in small boats across the Mediterranean sea. However, refugee flows in modern Africa have primarily been intraregional, beginning with the struggles against colonialism that led to the adoption of the broader definition of a refugee in the 1969 OAU Convention governing the specific aspects of refugee problems in Africa. ${ }^{106}$

By adopting a definition that differs from the now universalizing definition in the Refugee Convention, OAU member states effectively committed to sheltering these refugees within Africa. As Beyani writes, '[i]n the prevailing struggle for decolonisation in the 1960s, the causes of flight and the corresponding lack of protection were connected to the liberation struggle against colonial rule, with the result that commitment to the protection of refugees became a solid expression of solidarity between African states.' ${ }^{107}$ The region did not look to the outside world to help share responsibility, but focused instead on sharing responsibility among the members of the region. Article II(4) of the OAU Convention says,

Where a Member State finds difficulty in continuing to grant asylum to refugees, such Member State may appeal directly to other Member States and through the OAU and such Member States shall in the spirit of African solidarity and international co-operation take appropriate measures to lighten the burden of the Member State granting asylum.

105 See Ademola Abass and Dominique Mystris, 'The African Union Legal Framework for Protecting Asylum Seekers' in Abass and Ippolito (eds), Regional Approaches to the Protection of Asylum Seekers: An International Legal Perspective (Ashgate, 2014) 19.

106 OAU Convention, above n 60.

107 Beyani, above n 59, 13; James H S Milner, Refugees, the State and the Politics of Asylum in Africa (Palgrave Macmillan, 2009) 20. On the other hand, Abass and Mystris (above n 105, 22) draw on a more critical reading of the history of the OAU Convention and argue that it 'reflects a shift in Africa's approach to asylum-seeking from that of a protective nature to one focused more on containment.' 
Unfortunately, however, the provision has not been adequately implemented. Similarly, in the 1980s there was a largely unsuccessful attempt to involve the Global North in financial responsibility-sharing for refugees in Africa. This is examined in Chapter 5.

Since the end of the decolonization period in Africa, various internal struggles, including genocidal conflict in Rwanda and Burundi, have manifested in refugee flows. When examined closely, the refugeegenerating conflicts in Africa demonstrate that an internal explanation for refugee flows is frequently simplistic and that external actors often share moral culpability for refugees. ${ }^{108}$ The inheritance of the post-colonial African state is a combustible mix of ethnic divisions made worse by colonial policies of divide-and-rule, weak political structures and underdevelopment. ${ }^{109}$ While particularly vile dictators must bear a great deal of moral and legal responsibility, ${ }^{110}$ it is also notable how often they were supported by foreign powers, particularly during the Cold War. ${ }^{111}$

External factors also help to account for the distinct shift in asylum policy from the open, generous policy that prevailed during the struggle for decolonization to the restrictive policies of the 1990s. While one explanation for the change is that Africans may have been less sympathetic to refugees from independent states than colonized states, ${ }^{112}$ commentators have also noted the role of structural adjustment programmes in creating conditions ripe for xenophobia as citizens could not avail themselves of state services, while the refugees they hosted were assisted by the international community ${ }^{113}$ (although not adequately, leading to the African critique concerning lack of 'burden-sharing'). ${ }^{114}$

108 B S Chimni, 'The Geopolitics of Refugee Studies: A View from the South' (1998) 11(4) Journal of Refugee Studies 350, 351.

109 For analysis, see Milner, above n 107, 11; E Q Blavo, The Problems of Refugees in Africa: Boundaries and Borders (Ashgate, 1999) ch 1; Aristide R Zolberg, Astri Suhrke and Sergio Aguayo, Escape from Violence: Conflict and the Refugee Crisis in the Developing World (Oxford University Press, 1989) ch 2.

110 Makau wa Mutua, 'The Interaction Between Human Rights, Democracy and Governance and the Displacement of Populations' (1995) Special Issue Summer International Journal of Refugee Law 37.

111 Milner, above n 107, 13.

112 Aderanti Adepoju, 'The Dimension of the Refugee Problem in Africa' (1982) 81(322) African Affairs 21-35.

113 See particularly the detailed analysis of six countries in Cassandra R Veney, Forced Migration in Eastern Africa: Democratization, Structural Adjustment, and Refugees (Palgrave Macmillan, 2007) ch 3.

114 See Milner's discussion of ICARA I and II, Milner, above n 107, $26-8$. These two arrangements are discussed in detail in Chapter 5 of this book. 
Paradoxically, but perhaps not surprisingly, the moves to democratization - prompted by both internal voices responding to structural adjustment programmes ${ }^{115}$ and Western donors no longer interested in propping up African despots in order to contain the Soviet Union's influence ${ }^{116}$ - encouraged governments to pander to or exploit the xenophobic elements within their constituencies. Thus Veney wrote of Tanzania's turn to restrictive policies during the 1990s, that refugees' presence 'reinforced feelings of insecurity among local communities increasingly deprived of protection and provision from governments that were increasingly constrained fiscally and administratively, while at the same time the state could demonstrate its strength through the roundups, sweeps, beatings, and detention of refugees - all in the name of security.' ${ }^{117}$

\section{Asia and the Pacific}

Asia and the Pacific is the largest and most diverse region in the world, representing a huge number of cultures, religions and language groups, governmental systems and economic situations. It has several subregions: Central Asia, South Asia, Southeast Asia, Southwest Asia, and East Asia and the Pacific.

Economic and security cooperation has traditionally been more prominent in this region than promotion of human rights through regionalism. Various economic regional initiatives have sprung from the desire of Asian states, particularly Southeast Asian states, to insert themselves into the global economy and to avoid domination by great powers such as the United States. ${ }^{118}$ However, at the end of 2012, the Association of Southeast Asian Nations (ASEAN) adopted the ASEAN Human Rights Declaration, which includes several provisions pertinent to the rights of refugees, including the right to seek and receive asylum. ${ }^{119}$

115 See Veney's argument (above $\mathrm{n} \mathrm{113,66-7)} \mathrm{about} \mathrm{the} \mathrm{link} \mathrm{between}$ structural adjustment programmes and internal demands for democracy.

116 Milner, above n 107, 13.

117 Veney, above n 113, 84-5. Related phenomena such as immigration detention are common in the Western industrialized world too, as all states negotiate the impact of globalization on their sovereignty.

118 For a discussion of APEC, ASEAN initiatives and the China-ASEAN free trade agreement, see Helen E S Nesadurai, 'The Global Politics of Regionalism: Asia and the Asia-Pacific' in Mary Farrell, Björn Hettne and Luk van Langenhove (eds), Global Politics of Regionalism: Theory and Practice (Pluto Press, 2005) 155.

119 Art 16 of the ASEAN Human Rights Declaration provides that 'every person has the right to seek and receive asylum in another State in accordance 
Although the Declaration has been criticized for some departures from the universal human rights instruments and for the lack of NGO participation in its drafting, it is significant because, as Renshaw writes, 'no Southeast Asian government will ever be able to deflect criticism on the basis that human rights are an "external imposition", ${ }^{120}$

Prior to being eclipsed by the Syrian refugee crisis, Asia hosted the largest number of refugees in the world. ${ }^{121}$ Refugee flows have been both regional in origin, with the Indochinese refugee flow of 1975-1996 being one notable example, and, extra-regional (in the sense of a flow inwards to the region) with many refugees from the Middle East seeking asylum or transiting countries in Southeast Asia and seeking asylum in Australia over the last decade. Recent intra-regional flows have included Burmese and Vietnamese minority groups, Filipinos fleeing violence in the southern Philippines, and Hmong from Laos. ${ }^{122}$ Maritime arrivals of Bangladeshis and Rohingya, some of whom are refugees, rose sharply to 25000 arrivals in the first quarter of 2015. ${ }^{123}$

The Pacific island states present a very different picture from their larger Asian neighbours, generally receiving very few asylum seekers. Papua New Guinea has significant numbers of West Papuans who have crossed the border. It has also accommodated asylum seekers transferred from Australia under the so-called 'Pacific Solution', as has Nauru. These two countries have entered agreements with Australia to resettle refugees, as has Cambodia. ${ }^{124}$

Very few states in the Asia-Pacific region are parties to the Refugee Convention and/or the Refugee Protocol. Significantly, Asia-Pacific countries which receive large populations of refugees, such as Pakistan,

with the laws of such State and applicable international agreements'. The ASEAN countries are Brunei, Cambodia, Indonesia, Laos, Malaysia, Myanmar, the Philippines, Singapore, Thailand and Vietnam. See ASEAN Human Rights Declaration, above n 56.

120 Catherine Shanahan Renshaw, 'The ASEAN Human Rights Declaration 2012’ (2013) 13(3) Human Rights Law Review 557, 579.

121 UNHCR's Global Trends for 2013 report documents 3267500 refugees in the Asia-Pacific region. The figure for the Middle East and North Africa was 2556500 (UNHCR, Global Trends 2013: War's Human Cost (UNHCR, 2014) 12. In 2015, the number of Syrian refugees, who are predominantly hosted in the Middle East and North Africa, had reached over 4 million.

122 Pei Palmgren, 'Navigating a Hostile Terrain: Refugees and Human Rights in Southeast Asia' (2011) 5 Sociology Compass 323, 325.

123 UNHCR, South-East Asia Irregular Maritime Movements, January March 2015 <http://www.unhcr.org/554c6a746.html>.

124 See discussion in the Introduction to this book. 
Bangladesh, India, Indonesia, Malaysia and Thailand, are not parties to either the Refugee Convention or the Refugee Protocol. The Bangkok Principles on Status and Treatment of Refugees adopted by the advisory body, the Asian-African Legal Consultative Organization, indicate some consensus concerning the Convention definition of a refugee, but some states entered 'reservations' to this non-binding instrument. ${ }^{125}$ Customary international law is of course applicable, and some states in the region are bound by human rights treaties which protect against refoulement.

The People's Republic of China is a party to the Convention and Protocol, but it has not implemented its treaty obligations in domestic law. Other parties to the Convention and Protocol in the region are Japan, the Philippines, Cambodia, Papua New Guinea, Nauru, Fiji, South Korea, Timor Leste, the Solomon Islands, Tuvalu, Australia and New Zealand. Domestic protection in countries such as Cambodia, Papua New Guinea and Nauru is weak, ${ }^{126}$ with Australia, New Zealand and the Philippines providing better models of protection. Australia, however, has moved to 'offshore processing' on Nauru and in Papua New Guinea, precisely in

125 Final Text of the AALCO's 1966 Bangkok Principles, above n 65.

126 For criticism of the domestic refugee protection framework in Cambodia, see Human Rights Watch, 'Australia: Reconsider Naura Refugee Transfers to Cambodia', Human Rights Watch (online), 20 November $2014<$ http://www. hrw.org/news/2014/11/20/australia-reconsider-nauru-refugee-transfers-cambodia $>$. Nauru only acceded to the Refugee Convention on 28 June 2011 in order to be able to participate in the arrangement with Australia. It passed a national law regarding refugee status determination on 10 October 2012 (Refugees Convention Act 2012 (Nauru) <http://www.naurugov.nr/media/33059/refugees_convention_ act_2012.pdf $>$ ). It has also adopted legislation governing the detention centres in which transferees from Australia have been held. However, when UNHCR visited the centres on Nauru, which should be regarded as jointly controlled by Nauru and Australia, it noted various problems with the refugee status determination programme, and found that asylum seekers were arbitrarily detained and that conditions in the centres did not accord with international legal standards (UNHCR, UNHCR monitoring visit to the Republic of Nauru 7 to 9 October 2013 (UNHCR, 26 November 2013) <http://unhcr.org.au/unhcr/images/2013-1126\%20Report\%20of\%20UNHCR\%20Visit\%20to\%20Nauru\%20of\%207-9\%20 October\%202013.pdf $>$ ). Nauru has since announced that the centres will be open centres. UNHCR expressed similar concerns about the situation in Papua New Guinea, where there was no domestic legal framework in place, detention was arbitrary, and conditions in detention were substandard (UNHCR, UNHCR Mission to Manus Island, Papua New Guinea 15-17 January 2013 (UNHCR, 4 February 2013) <http://unhcr.org.au/unhcr/images/2013-02-04\%20Manus\%20 Island\%20Report\%20Final.pdf $>$ ). 
order to deter boat departures for Australia. ${ }^{127}$ Japan recognizes few refugees, but it is developing a strong interest in refugee protection, as demonstrated by its decision to become the first Asian country to join UNHCR's resettlement programme. ${ }^{128}$

When states in the region have sheltered refugees, they have often done so through informal arrangements instead of legally binding instruments, and UNHCR has a fragile relationship with many countries in the region. Most refugees in the Asia-Pacific region are living in countries where they have no legal right to work. Consequently, many refugees are forced to work illegally without any labour protection, survive on money that is sent to them by family members, rely on limited social services provided by NGOs, and/or live in destitute conditions in the host country. ${ }^{129}$ For many refugees, these conditions may leave them no choice but to leave the country of first asylum and move onwards in search of adequate protection for themselves and their families.

The lack of status for refugees in the region is the cause of many human rights violations ${ }^{130}$ and significant problems for states, such as corruption, trafficking and smuggling. ${ }^{131}$ While this problem may be ascribed, in part, to 'government weakness', ${ }^{132}$ it is also the case that a positive policy of recognition would diminish refugees' vulnerability to exploitation, benefiting the state. Failure to recognize refugees does not avoid legal obligations owed to them as a matter of customary international law or under human rights treaties, while a policy of recognition can open up mechanisms of protection that do not require much additional activity by the state. Access to the formal labour market, for example, would mean that the market could provide a form of protection to refugees, as refugees would no longer be subjected to the exploitation

127 See discussion in the Introduction to this book.

128 UNHCR, 'Welcome to Japan: first Asian Country joins UNHCR's resettlement programme', News Stories (online), 28 September $2010<\mathrm{http}: / /$ www.unhcr.org/4ca1dbe66.html>.

129 For discussion of the situation in Thailand, Malaysia and Indonesia, see Penelope Mathew and Tristan Harley, Refugee Protection and Regional Cooperation in Southeast Asia: A Fieldwork Report (Australian National University, March 2014) and Jesuit Refugee Service Asia Pacific, The Search: Protection Space in Malaysia, Thailand, Indonesia, Cambodia and the Philippines (JRS Asia Pacific, 2012).

130 Jesuit Refugee Service Asia Pacific, above n 129.

131 Palmgren, above n 122, 323, 332.

132 Alan Dupont, 'Refugees and Illegal Migrants in the Asia-Pacific Region' in William Maley et al (eds), Refugees and the Myth of the Borderless World (Australian National University, 2002) 9, 12. 
that flows from lack of legal status. Of course, this assumes there are mechanisms to protect workers' rights more generally, which is often not the case and may result in a pull factor for unauthorized migrant workers. Access to the labour market would also greatly minimize the need for refugees to move onwards in an irregular way in search of protection. Reduction in onward secondary movement would, in turn, diminish the market for people smugglers.

If recognition of refugees can provide solutions to problems as states perceive them, ${ }^{133}$ what explains the refusal to recognize them? The policies of many of the states in the region are partly explained by the process of state-building in the region. As Dupont writes,

Western governments have traditionally considered unregulated population movements ... to be a matter of 'low politics' (pertaining to the wealth and welfare of the citizens of the state) rather than 'high politics' (associated with security and the continued existence of the state). Asians, on the other hand, have been more sensitive to the national security implications of refugee movements and illegal migration for historical and cultural reasons - multiethnic Southeast Asia particularly so, because of endemic racial and religious tensions and the preoccupation of political elites with nation building and regime maintenance. ${ }^{134}$

While states infrequently provide reasons as to why they do not accede to the Convention and/or Protocol, UNHCR suggests that states 'may be apprehensive about multilateral engagement, loss of flexibility, costs or the potential for abuse'. ${ }^{135}$ Interrelated with the fear of abuse is the fear of pull factors common to most governments around the globe. These fears persist despite the countervailing realities. It is clear that the push factors of persecution, conflict and human rights violations result in movement, regardless of governments' refusal to recognize this, while people seeking work come because work is available in the informal

133 See the comments of Mr Rick Towle, Regional Representative UNHCR, in Report from the Colloquium on Refugees, Regionalism and Responsibility, 22-23 August 2013 (Australian National University, 2013) 4.

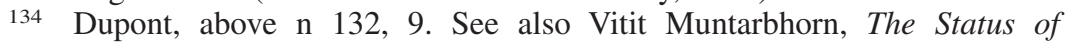
Refugees in Asia (Clarendon Press, 1992) ch 1.

135 UNHCR, The State of the World's Refugees: In Search of Solidarity (Oxford University Press, 2012) 37. 
economy. ${ }^{136}$ Refugee status determination procedures enable governments to know who is in the community and whether their reasons for being there are recognized as a matter of international law. ${ }^{137}$

Alternatively, governments in the region 'may see the Convention as representing "Western" standards of treatment that some cannot provide, or as concerned only with "political" refugees when most of today's refugees flee from conflict situations'. ${ }^{138}$ Sara Davies has argued that the reason why the majority of Southeast Asian states have refused to accede to the Convention and the Protocol is because 'they have never felt obliged to do so'. ${ }^{139}$ According to Davies, this lack of a sense of obligation derives from two sources. First, it derives from the belief among Southeast Asian states that both the Convention and the Protocol are Eurocentric legal instruments that are largely irrelevant when dealing with the irregular migration movements occurring in Southeast Asia. Second, it derives from the CPA, which focused on resettlement in exchange for temporary refuge rather than on local integration. ${ }^{140}$

Regional efforts concerning refugees in the Asia-Pacific have proved limited, and the one 'qualified success' - the CPA 141 - may have entrenched an attitude that responsibility for refugees lies with Western countries. A current initiative, the Bali Process on People Smuggling, Trafficking in Persons and Related Transnational Crime ${ }^{142}$ has until recently focused on people smuggling, rather than protection, and the potential of the understandings around the regional cooperation framework $^{143}$ is uncertain.

In September 2012, Bali Process Co-Chairs Australia and Indonesia officially opened a Regional Support Office (RSO) in Bangkok, Thailand

136 See, for example, Gordon Howard Hanson, The Economic Logic of Illegal Immigration (Council on Foreign Relations, 2007); Georges Tapinos, 'Irregular Migration: Economic and Political Issues' in Combating the Illegal Employment of Foreign Workers (OECD, 2000) 13.

137 See the comments of Mr Rick Towle, above n 133, 4.

138 UNHCR, The State of the World's Refugees, above n 135.

139 Sara E Davies, Legitimising Rejection: International Refugee Law in Southeast Asia (Martinus Nijhoff, 2008), 18.

140 Ibid.

141 The CPA is discussed in Chapter 4 of this book.

142 The Bali Process on People Smuggling, Trafficking in Persons and Related Transnational Crime <http://www.baliprocess.net>.

143 See the discussion of the regional cooperation framework in the Introduction to this book. 
to operationalize the regional cooperation framework. ${ }^{144}$ The RSO has commenced a number of projects for tackling irregular migration in the region and these include refugee protection elements. Non-state action may also prove significant. There is, for example, a vibrant network of refugee NGOs - the Asia Pacific Refugee Rights Network. ${ }^{145}$

\section{The Middle East}

Regionalism in the Middle East - a Eurocentric term often used in this book because the term Arab World (also used in this book) captures a narrower slice of the population of this region - has generally been less effective in this region than others. Institutions such as the Arab League (formally speaking the League of Arab States) have not been able to respond effectively to problems besetting the region such as armed conflict. ${ }^{146}$ This is despite the high degree of cultural similarity in many respects across this region.

Arguably, states in this region are linked not so much by an imagined community as through the 'interaction of conflict'. ${ }^{147}$ Some authors have described the Arab world as cooperating best when faced with a common enemy, but that otherwise competition is the default. For example, Gariup writes that "unity and conflict are the two facts of stereotyped Arab culture. An old Bedouin Arabic Proverb recites: "I and my brothers against my cousin; I and my cousins against the stranger (against the world)".' 148

144 Bali Process Steering Group, 'Note on the Operationalisation of the Regional Cooperation Framework in the Asia Pacific Region' (Paper presented at Fifth Meeting of the Bali Process Ad Hoc Group Senior Officials, Sydney Australia, 12 October 2011) 1.

145 Asia Pacific Refugee Rights Network <http://www.aprrn.info/1/>. For discussion of APRRN, see Savitri Taylor, 'Civil Rights and the Fight for Refugee Rights' in Angus Francis and Rowena Maguire (eds), Protection of Refugees and Displaced Persons in the Asia Pacific Region (Ashgate, 2013) 13. APRRN is developing its own vision for protection and plan of action.

146 Fawcett, above n 4, 429, 441.

147 Helena Lindholm-Schulz and Michael Schulz, 'Israel, Palestine and Jordan: Triangle of Peace or Conflict?' in Björn Hettne, András Inotai and Osvaldo Sunkel (eds), The New Regionalism and the Future of Security and Development (Palgrave Macmillan/UNU-WIDER, 2000) 144, 147.

148 Monica Gariup, 'Regionalism and Regionalization: the State of the Art from a Neo-Realist Perspective' in Cilja Harders and Matteo Legrenzi (eds), Beyond Regionalism?: Regional Cooperation, Regionalism and Regionalization in the Middle East (Ashgate, 2008) 69. 
In addition to the Arab-Israeli conflict and the Palestinian refugee problem, which have been a major focus of the Arab world and the Arab League, other sources of conflict and competition have served to diminish the prospects of regional cooperation on many issues and to generate refugee flows. Writing in 1997, well before the Arab Spring, Abi-Aad and Grenon argued that

the different factors of instability and sources of conflict faced by the states of the Middle East are broadly comparable, and include the autocratic nature of the regimes and the struggle for power, interstate ideological cleavages, military antagonisms and race, ambition and structure of armed forces, sectarian minorities and religious rivalry, ethnic heterogeneity and minorities, border disputes, disparity in economic development, social impacts of economic constraints, divergence in petroleum policies, struggles over water, demographic explosion, disparity in population growth, and troubles caused by foreign labour migration, internal flight and flows of refugees. These factors are most of the time interrelated and interdependent. ${ }^{149}$

While pan-Arabism could provide a basis for regionalism, as it is the basis for the Arab League, it is problematic. As Romano and Brown point out, the ethnic nationalist focus of the Arab League carries 'a dangerous potential for exacerbating conflicts with "out-groups".' 150 They also note that the authoritarian nature of the regimes involved means that any international organization established by them is likely to be used 'to deflect international criticism of their policies.' ${ }^{151}$ Abi-Aad and Grenon argue that, in turn, the failure to seek democratic legitimation has exposed regimes in the region to extremism. ${ }^{152}$

The 'common enemy' served as a justification for 'strong' autocratic regimes ${ }^{153}$ and, instead of seeking democratic legitimation, governments sought to buy their citizens' acquiescence through welfare and services. ${ }^{154}$ As in other regions, the Cold War bolstered autocratic regimes as the USA was prepared to support many of them as a bulwark against pro-Soviet regimes and because of its interests in securing oil supplies,

149 Naji Abi-Aad and Michel Grenon, Instability and Conflict in the Middle East (St Martins Press, 1997) 10.

150 David Romano and Lucy Brown, 'Regional Organizations, Regional Identities and Minorities' in Cilja Harders and Matteo Legrenzi (eds), Beyond Regionalism?: Regional Cooperation, Regionalism and Regionalization in the Middle East (Ashgate, 2008) 157, 167.

151 Ibid 166.

152 Abi-Aad and Grenon, above n 149, 5.

153 Ibid 5.

154 Ibid 21. 
among others. ${ }^{155}$ In 2010, beginning with the self-immolation of a Tunisian street vendor, the protests known as the Arab Spring led to the end of many regimes in the region, but the aftermath continues to unfold in repression and conflict, ${ }^{156}$ including the Syrian conflict that has resulted in over 4 million refugees.

Regional efforts at human rights protection are relatively weak. The Arab Charter on Human Rights entered into force in 2008. ${ }^{157}$ It does not have a complaints mechanism and not all of its provisions are consistent with the international instruments. ${ }^{158}$ However, 13 of the 22 League Member States are party and the Arab Human Rights Committee reviews reports submitted periodically by states parties. ${ }^{159}$

Refugee flows in the Middle East have been primarily intra-regional, stemming from persecution of religious minorities as well as political persecution of dissidents, ${ }^{160}$ but outflows of refugees and other displaced persons have often involved large-scale foreign intervention. The protracted Afghan refugee situation was initially sparked by the Soviet military intervention of 1979. The two Iraq wars - the first legally justified as a collective defence operation and by a UN Security Council resolution, ${ }^{161}$ the second being illegal as a matter of international law also caused massive displacement.

These examples of intervention are relatively recent, but intervention in the Middle East and consequences in terms of refugee flows has a much longer history. The end of the Ottoman, Russian and Austro-Hungarian

155 Ibid 8.

156 For analysis, see, for example, John Davis (ed), Arab Spring and Arab Thaw: Unfinished Revolutions and the Quest for Democracy (Ashgate, 2013).

157 League of Arab States, Arab Charter on Human Rights, adopted on 15 September 1994 (entered into force 15 March 2008).

158 See the criticisms in Mervat Rishmawi, 'The Revised Arab Charter on Human Rights: A Step Forward?' (2005) 5 Human Rights Law Review 361, 363-5.

159 Unfortunately, there is not much English language material available at the Arab Human Rights Committee's website, meaning that it is difficult for English-speakers to assess the effectiveness of the reporting process.

160 For example, the creation of numerous waves of refugees from Iraq prior to the US invasion in 2003 have been described as sharing a similar intent, "the consolidation and homogenization of various Iraqi regions through the expulsion of unwanted populations' (Nabil Al-Tikriti, 'There Go the Neighbourhoods: Policy Effects vis-à-vis Iraqi Forced Migration' in Dawn Chatty and Bill Finlayson (eds), Dispossession and Displacement: Forced Migration in the Middle East and North Africa (Oxford University Press, 2010) 249, 258).

161 SC Res 678, UNSCOR, 2963rd mtg, UN Doc S/RES/0678 (29 November 1990). 
empires forced many refugees into the Middle East. ${ }^{162}$ Dawn Chatty documents the demise of the Ottoman empire and its largely successful policies promoting peaceful co-existence of religious and ethnic groups, as a result of the rise of nationalism in the nineteenth century and foreign support or manipulation of various minorities. ${ }^{163}$ The most protracted refugee situation in the world, the Palestinian refugee situation, resulted from the establishment of Israel and is, as Chatty states, a creature of the two world organizations - the United Nations and its predecessor, the League of Nations. ${ }^{164}$

The Palestinian refugee problem is both an historical source of dissatisfaction with the United Nations and a long-standing example of the forbearance shown to Arab refugees, but it is dealt with outside the confines of the Refugee Convention as a special case. Article 1D of the Refugee Convention formally excludes from the protection of the Convention those Palestinians receiving assistance from the UN Relief and Works Agency for Palestine Refugees in the Near East (UNRWA) as does paragraph 7(c) of the UNHCR Statute. This has been described as 'a symbol of the international commitment to the Palestinian people, a reflection of the fact that their refugee status was different than that of other refugees, that they should benefit from the international community's assistance until the problem was resolved, that their case was not a simple one of resettlement in a third country or integration in the country of first asylum.' ${ }^{165}$ The Palestinian refugee problem may also account for Arab States' unwillingness to accede to the Convention and Protocol as it is feared this might open up durable solutions other than repatriation. 166

Unfortunately, the special regime for Palestinians has not had better outcomes than the Convention system in terms of protection and access to durable solutions. States in the region responded to the Palestinian

162 Dawn Chatty, 'Epilogue: Dispossession and Forced Migration in 21st century Middle East and North Africa: The Way Forward' in Dawn Chatty and Bill Finlayson (eds), Dispossession and Displacement: Forced Migration in the Middle East (Oxford University Press, 2010) 273, 274.

163 Dawn Chatty, Displacement and Dispossession in the Modern Middle East (Cambridge University Press, 2010) ch 2.

164 Ibid 208.

165 Ilter Turkmen, quoted in Don Peretz, Palestinian Refugees and the Middle East Peace Process (USIP Press, 1993) 109-10. For the drafting history, see Brenda Goddard, 'UNHCR and the International Protection of Palestinian Refugees' (2009) 28 Refugee Survey Quarterly 475.

166 Goddard, ibid 505. 
refugees with the Casablanca Protocol, ${ }^{167}$ granting Palestinians many rights on paper, but it is often not applied. ${ }^{168}$ Hieronymi and Jasson observe that the exclusion of Palestinians from the international refugee regime has 'helped maintain the fiction that the Palestinian refugee situation was temporary, and would be resolved with the final elimination of Israel. Importantly, it also averted an obligation to facilitate local integration and third-country resettlement.' ${ }^{169}$ They argue that this has resulted in generations of refugees, and their radicalization. ${ }^{170}$

As Peretz documents, various schemes were developed in the 1940s and 1950s for regional solutions for Palestinian refugees through a mix of permanent settlement in neighbouring states combined with development assistance and repatriation by Israel, but these failed, while solutions involving resettlement outside the region met with the objection, from both refugees and neighbouring states, that resettlement means forfeiting the right of return for Palestinians. ${ }^{171}$ It is apparent that resolution of the root causes of displacement is the stumbling block to a regional arrangement for the Palestinian refugees.

There is little by way of legal protection for most refugees in this region. Most Middle Eastern states are not party to the Refugee Convention or Protocol. Bahrain, Iraq, Jordan, Kuwait, Lebanon, Oman, Qatar, Saudi Arabia, Syria and the United Arab Emirates, for example, are not parties to either instrument. Iran and Yemen are parties. Egypt and Afghanistan (part of the 'greater Middle East') ${ }^{172}$ and Israel (geographically within the region) are also parties.

One regional effort, the 1994 Arab Convention on Regulating the Status of Refugees in the Arab Countries, ${ }^{173}$ adopted by the League of Arab States, is not in force. On paper, it is an interesting document. It adopts a broad definition of refugee, encompassing in addition to the 1951 Convention definition, 'any person who unwillingly takes refuge in a country other than his country of origin or his habitual place of

167 League of Arab States, Protocol for the Treatment of Palestinians in Arab States (Casablanca Protocol), (11 September 1965) <http://www.refworld.org/ docid/460a2b252.html>.

168 Goddard, above n 165, 507.

169 Otto Hieronymi and Chiara Jasson, 'Palestinian Refugees: The Need for a New Approach' (2002) 4(4) Global Dialogue 110, 113.

170 Ibid 113-14.

171 Peretz, above n 165, 92-114.

172 It has been noted that there are no natural borders, leading to different opinions on the size of the region. Lindholm-Schulz and Schulz, above n 147, 148.

173 Arab Convention on Regulating Status of Refugees, above n 67. 
residence because of sustained aggression against, occupation and foreign domination of such country or because of the occurrence of natural disasters or grave events resulting in major disruption of public order in the whole country or any part thereof'. ${ }^{174}$ However, with respect to non-refoulement and asylum, there is an insipid commitment to 'undertake every possible effort, within the limits of their respective national legislation, to accept refugees defined in Article 1 hereof' 175 and a provision concerning refoulement that obliges states to 'temporarily accept a refugee should his expulsion or return (refoulement) threaten his life or freedom'. ${ }^{176}$ Most other refugee rights contained in the Refugee Convention are not expressly referred to, with a weak catch-all provision requiring states to 'exert every possible effort, to ensure that refugees are accorded a level of treatment no less than that accorded to foreign residents on their territories.' ${ }^{177}$ Concerning responsibility-sharing, the Convention provides that 'should a Contracting State face difficulty in granting or continuing to grant right of asylum under this Convention because of sudden or mass influx or for any other compelling reasons, the rest of the Contracting States shall, at the request of such State, take appropriate measures, severally or jointly as to alleviate the burden of the asylum-providing State.' 178

In practice, many refugees have been sheltered and sometimes treated very well by Middle Eastern states. The Syrian refugee crisis illustrates this point. Similarly, the presence of other refugees - Iraqis, and Afghans (who are not Arabs), for example - has often been tolerated and on a grand scale, but rights such as the right to work have not been recognized, leading to onward secondary movement to other regions. ${ }^{179}$

The lack of legal protection may correspond to the idea of pan-Arab hospitality. As Victoria Mason explains, in accordance with pan-Arab hospitality, fellow Arabs are treated as 'visitors' and 'guests', while the

\footnotetext{
174 Ibid Art 1.

175 Ibid Art 3.

176 Ibid Art 8(2).

177 Ibid Art 5.

178 Ibid Art 14.

179 For a discussion of the failure of many Middle Eastern countries to permit Iraqi refugees to work, see Amnesty International, Rhetoric and Reality: the Iraqi Refugee Crisis (June 2008) AI Index MDE 14/011/2008; International Crisis Group, 'Failed Responsibility: Iraqi Refugees in Syria, Jordan and Lebanon' (10 July 2008) Middle East Report 77.
} 
word 'refugee' is reserved for the Palestinian situation. ${ }^{180}$ While a notion of hospitality would be a welcome respite from the xenophobia at work in so many refugee situations around the world, it has limitations. Mason distinguishes between the rhetoric of pan-Arab hospitality and its reality, pointing to the inherent power imbalance in the 'host/guest' binary. ${ }^{181}$ Noting the moral panics about refugees in Jordan and the similarity to moral panics about refugees elsewhere, she argues that the hospitality paradigm is a convenient way of justifying rejection of refugees, as the host nation can construct a discourse in which the deviant refugee has abused the host state's hospitality. ${ }^{182}$

\section{THE MERITS OF REGIONAL ARRANGEMENTS FOR REFUGEES}

The preceding exploration of the historical background concerning refugees and regionalism and the situation in the five major regions of the world provides important context for an exploration of the theoretical advantages of regional arrangements for the protection of refugees. The merits of regional arrangements have frequently been expounded by the Executive Committee that approves the programme of the United Nations High Commissioner for Refugees (ExCom). For example, in Executive Committee Conclusion No 22, ExCom recommended that 'action should be taken bilaterally or multilaterally at the regional or at the universal levels' and '[p]rimary consideration should be given to the possibility of finding suitable solutions within the regional context'. ${ }^{183}$ Similarly, in Executive Committee Conclusion No 81, ExCom encouraged 'States and UNHCR to continue to promote, where relevant, regional initiatives for refugee protection' ${ }^{184}$ In the 2000 Note on Protection, UNHCR stated

180 Victoria Mason, 'The Im/mobilities of Iraqi Refugees in Jordan: PanArabism, "Hospitality" and the Figure of the "Refugee"", (2011) 6(3) Mobilities 353, 354. Mason draws on Geraldine Chatelard, 'What Visibility Conceals: Re-embedding Refugee Migration from Iraq' in Dawn Chatty and Bill Finlayson (ed), Dispossession and Displacement: Forced Migration in the Middle East and North Africa (Oxford University Press, 2010) 17.

181 Mason, ibid 359.

182 Ibid 367. This is also a familiar trope in countries that do not have an equivalent notion of hospitality.

183 UNHCR Executive Committee, Conclusion No 22 (XXXII), 'Protection of Asylum-Seekers in Large-Scale Influx' (1981), IV (2).

184 UNHCR Executive Committee, Conclusion No 81 (XLVIII), 'General Conclusion on International Protection' (1997), [k]. 
that '[h]armonized regional protection approaches are an important means of strengthening the international protection regime. UNHCR's active participation in the design of these regional approaches has sought to guarantee consistency with universal standards and to ensure burden sharing and international solidarity, while responding to specific regional concerns.' 185

Acceptance of regionalism as a tool for refugee protection may reflect an optimism about regional protection that is based on generally positive experience. Regional initiatives within international refugee law have often strengthened the international refugee protection regime. As we have seen, regional instruments that have been developed since the 1951 Refugee Convention have often expanded the categories of persons who benefit from protection. Furthermore, these regional instruments specifically call for states that have not already done so to become party to the Refugee Convention as modified by the 1967 Protocol, recognizing that the regional instruments are complements to the universal instruments. ${ }^{186}$ Normatively speaking, however, the benefits of a universal approach, on the one hand, or a regional approach, on the other, are open to debate.

\section{Universalism}

Universalism has its pros and cons. On the one hand, an inclusive multilateral approach tries to ensure that all states are bound by a common framework. On the other hand, this common framework may, because of the number of parties involved in initial negotiations, reflect only the lowest common denominator or result in gridlock. ${ }^{187}$ In turn, Eckersley argues that this may have perverse results as justice either will not be done or serious injustices will not be prevented. ${ }^{188}$

Arguably the Refugee Convention and Protocol illustrate the first problem - acceptance of the lowest common denominator. As was commented at the time of negotiation 'the draft Convention had at times been in danger of appearing to the refugee like the menu at an expensive

185 Note on International Protection, UN GAOR 51st sess, UN Doc A/AC.96/930 (7 July 2000) 13.

186 OAU Convention, above n 60, paragraphs 9 and 10. Cartagena Declaration on Refugees, above n 61 operative paragraph 2; see also preambular paragraphs 3 and 4 of the Recast Qualification Directive, above n 63.

187 See Thomas Hale, David Held and Kevin Young, Gridlock: Why Global Cooperation is Failing When We Need It Most (Polity, 2013).

188 Robyn Eckersley, 'Moving Forward in the Climate Negotiations: Multilateralism or Minilateralism?' (2012) 12(2) Global Environmental Politics 24, 33. 
restaurant, with every course crossed out except, perhaps, the soup, and a footnote to the effect that even the soup might not be served in certain circumstances.' ${ }^{189}$ In relation to responsibility-sharing in particular, it is notable that the efforts to include a provision, albeit non-binding, concerning admission and 'burden' sharing failed; there is simply a reference to the 'heavy burdens' imposed by hosting refugees in the preamble to the Convention, a reference that was also controversial. ${ }^{190}$

\section{Regionalism}

There are good reasons to promote regional cooperation in refugee protection. To begin with, refugee movements are frequently regional in location and impact. Regional actors may therefore have a more direct concern in addressing these movements, particularly if there are impacts in terms of regional stability. The OAU Convention acknowledges that refugee problems are a source of friction among many states and it is desirable at the regional level to eliminate the source of such discord. ${ }^{191}$

Arguably, regional actors may also be better equipped in some respects to respond because they have region-specific knowledge and could be more capable of coordinating and tailoring protection programmes to the particular needs of refugees. For refugees, this regional cooperation could result in greater certainty in finding sanctuary and greater opportunity for the enjoyment of basic social and economic rights, such as the right to work or the right to an adequate standard of living.

A final motivation for regional cooperation in refugee protection is the greater possibility of uniform agreement between nation states in the region. In an international political environment where refugee rights are not yet universally accepted, let alone universally implemented, regional agreement might be a more realistic and achievable goal. As Inis L. Claude wrote in his work on international organization, regional approaches to international problems are often more suitable than global ones because they confine state commitments to manageable sizes within segments of the globe which share common loyalties and/or cultural

189 Mr Rees, representing Standing Conference of Voluntary Agencies, in Conference of Plenipotentiaries on the Status of Refugees and Stateless Persons: Summary Record of the Nineteenth Meeting: Travaux Préparatoires, 26 November 1951 <http://www.unhcr.org/3ae68cda4.html>.

190 See the discussion of the travaux, above $\mathrm{n} 69$.

191 OAU Convention, above n 60, preamble 3. 
practices. ${ }^{192}$ Additionally, regional arrangements may plug gaps at the global level, such as those that result from gridlock. Stein suggests that:

regional efforts, by regional international organizations and ad hoc groupings of regional actors, occur when the region either has rejected the solution advanced by the international community or when the international community has taken little or no action to achieve a solution. ${ }^{193}$

Regions can theoretically collaborate in initiatives such as research and training development, institution and programme sharing, harmonized jurisprudence and combined efforts to tackle root causes of flight. Additionally, participating states could allocate distinct protection roles according to differing levels of expertise and capacity. States could assign tasks such as processing refugee claims, hosting refugees temporarily, resettling refugees permanently, and providing financial support. For states, regional cooperation in this sense could allow for more appropriate and efficient solutions to refugee influxes, reduced financial expenditure (through the elimination of duplicative processes where appropriate) and better diplomatic relationships between participants. For refugees, this cooperation could result in enhanced protection and the greater likelihood of receiving assistance closer to home.

Different forms of regionalism can obviously shape the form of refugee protection prevailing in a particular region. Some of the regional arrangements concerning refugees discussed in this book have been adopted under the auspices of existing regional organizations. For example, the CEAS has been created through legislation adopted by the EU. The CEAS is thus part of a regionalist project: a project that has conflicting visions of Europe at its heart. On the one hand, refugees have found it difficult to enter the EU lawfully, given the focus on controlling the external border to Europe, and the EU has been described as 'Fortress Europe' as a result. On the other hand, the imagined community of Europe as a space of freedom, justice and security, a place committed to protection of human rights because of the European experience during the Second World War, pulls in a different direction and serves to protect those who do arrive in the EU.

192 Inis L Claude, Swords into Plowshares: The Problems and Progress of International Organization (Random House, 1964) 102.

193 Barry Stein, 'Regional Efforts to Address Refugee Problems' (Paper presented at the Annual Meeting of the International Studies Association, Toronto, 21 March 1997). 
Many of the other initiatives discussed in this book appear to be ad hoc forms of regional cooperation, designed to implement (more or less) the global norm of non-refoulement, whether or not the participating states have ratified relevant instruments. They are often premised on the hope that a definitive solution will be found to a particular, regional refugee crisis. As Stein writes,

[c]losely related to regional efforts, but distinct from them, is the idea of a comprehensive response to refugee problems. A comprehensive approach is one in which a variety of different but concerted measures are brought to bear on a refugee situation. The 'package' needed for a solution can include: temporary asylum, non-refoulement, voluntary repatriation with UNHCR monitoring in the country of origin, as well as assistance for reintegration and perhaps local integration or resettlement of refugees who refuse to return.

$[\ldots]$

Regional approaches are likely to be comprehensive responses because of the interdependence of the concerted measures. For example, refugee camps in the country of asylum cannot be closed unless the country of origin is willing to remove the causes of flight and accept the returnees. However, the removal of the causes of flight may be partially dependent on neighboring countries restricting the flow of political and military aid to insurgent groups. ${ }^{194}$

While regional initiatives have the potential to strengthen the international refugee protection regime, regionalism is not necessarily a positive development for refugees. Stein identifies six reasons behind the move to regionalism that are not all motivated by the best interests for refugees, namely:

the shift from colonial struggles to internal conflicts;

the end of the Cold War and the 'use' of refugees as an element in the conflict;

growing concern by industrialized countries to contain refugee flows from the developing world;

the refusal of regional actors to play previously assigned roles;

the resistance of donor countries and asylum countries in the developing world to support continued burden-sharing;

194 Stein, ibid. On 'comprehensive' approaches, see further, Martin Gottwald, 'Back to the Future: The Concept of "Comprehensive Solutions"' (2012) 31(3) Refugee Survey Quarterly 101. 
and the need for regional actors to respond when global action proves inadequate. ${ }^{195}$

Regionalism can also create disparities in treatment between different regions in the world, and it can undermine the pursuit of universality in refugee rights protection. For example, African states have perceived a distinct lack of interest in refugee flows within the African region as compared with other regions. Resettlement outside the region of refugee flows can be hindered when resettlement states adhere too closely to the definition of a refugee set out in the Refugee Convention while other regions are using broader definitions that encompass all victims of generalized violence. Further, the containment measures adopted by the Global North may well be succeeding as UNHCR's statistics show that over the last ten years, the numbers of refugees sheltered in the developing world has increased by over 10 per cent. ${ }^{196}$ These policies have ensured that the costs of providing asylum to refugees still fall primarily, perhaps increasingly so, on the world's poorest states.

\section{Minilateralism}

Another variant on multilateralism that intersects with regional approaches is the concept of minilateralism, which has been deployed as a tool to overcome gridlock in climate change negotiations. Minilateralism seeks to 'bring to the table the smallest possible number of countries needed to have the largest possible impact on solving a particular problem' ${ }^{197}$ A further variation on miniateralism is 'inclusive minilateralism', which brings together 'the most capable, the most responsible and the most vulnerable'. ${ }^{198}$ Robyn Eckersley describes these parties in the context of climate change as follows:

the most capable are the leading developed economies (using GDP as a proxy for capacity), which have the greatest capacity to assist to reduce emissions through technological innovation, and the greatest capacity to assist developing countries with mitigation and adaption. The most responsible countries are the parties with the biggest historical, aggregate and forecasted emissions, and therefore the biggest scope to reduce emissions, with appropriate acknowledgement of differences in per capita emissions and development

\footnotetext{
195 Stein, ibid 1.

196 See UNHCR, Global Trends 2013, above n 121, 2.

197 Moisés Naím, 'Minilateralism' (2009) (173) Foreign Policy 136, 135.

198 Eckersley, above n 188, 26.
} 
need. The most vulnerable are the parties that are expected to suffer the harshest impacts of climate change, and have the least capacity to adapt. ${ }^{199}$

In the refugee context, inclusive minilateralism would certainly involve developing countries as some of the most vulnerable, given that they host 86 per cent of the world's refugees, and developed countries as some of the most capable given their economic strength, institutional and technical knowledge, strong democratic structures, and so on, but there are interesting questions as to who is the most responsible, how to include refugees' voices, and other questions as to how to measure capacity.

In both areas - climate change and refugee flows - there is a marked divide between the developed (Northern) and developing (Southern) regions of the globe. Unfortunately, however, this is where the similarities may end. For while the 'grand bargain' to be struck in the context of climate change is 'Southern participation in return for Northern assistance', ${ }^{200}$ Southern states are both the greatest generators of and hosts for refugees and there appears to be little incentive for Northern participation. Alexander Betts has argued for a grand bargain between North and South concerning refugee flows, involving targeted development assistance that helps both refugees and Southern host populations and, simultaneously, diminishes onward movement of refugees to the North. ${ }^{201}$ However, unlike carbon dioxide emissions, which clearly cannot be contained, Northern states are willing to invest in containment of refugees in the South through deterrence mechanisms rather than by providing assistance to Southern states. As Matthew Gibney has written, these deterrence mechanisms can manifest as a kind of regionalism in which the North keeps the South out. ${ }^{202}$

199 Ibid 35. Interestingly, the G20 has arguably made some progress on climate change, despite the fact that it probably only represents the most capable and the most responsible rather than the most vulnerable, perhaps showing the value of exclusive minilateralism.

200 Ibid 30.

201 Alexander Betts, 'Development Assistance and Refugees: Towards a North-South Grand Bargain?' (Forced Migration Policy Briefing 2, Refugee Studies Centre, 2009). Betts (11-12) acknowledges his proposal is 'analogous' to that of Hathaway and Neve and the idea that North and South would have 'common but differentiated responsibility' (see James C Hathaway and R Alexander Neve, 'Making International Refugee Law Relevant Again: A Proposal for Collectivized and Solution-Oriented Protection' (1997) 10 Harvard Human Rights Journal 115).

202 Matthew J Gibney, 'Forced Migration, Engineered Regionalism and Justice between States' in Susan Kneebone and Felicity Rawlings-Sanaei (eds), 
In turn, some Southern states are concerned that investment in refugee protection will simply act as a 'pull factor' and exacerbate, rather than eliminate, the problem. Thus, they too engage in deterrence measures of their own. Frequently, while the North invests in preventing asylum seekers and migrants from arriving at the border, the South declines to provide assistance in the hope that asylum seekers and migrants will return home. ${ }^{203}$

\section{CONCLUSION}

As we have seen, 'regionalism' and 'regions' are contestable ideas. However, it is clear that different approaches to refugee protection have been taken in the five major regions of the globe, so it is possible to talk meaningfully about regionalism and refugee protection. One of the aims of this book is to explore what kind of regionalism has been reflected in regional arrangements for refugee protection. Is it regionalism based on a conception of an imagined community, whether that be solidarity among like states or a commitment to universal values of human rights? If so, how does this affect responses to refugees? Are there different responses to refugees from within as opposed to those coming from outside the region, for example? Given the tendency of regionalism to focus on 'insiders', is there an accompanying tendency towards keeping extraregional refugees out? How are responsibilities for refugees shared within the region? Do some regions refuse to accept responsibility for refugees in the sense of offering them a durable solution within the region? Is it necessary to move beyond regions and encourage inter-regional cooperation?

We think it is likely that cooperation between the most capable, the most responsible and the most vulnerable in refugee protection could achieve good outcomes in refugee protection. However, there are a number of uncertainties to explore. One of the issues we explore in Chapter 3 is how 'capacity' is to be measured, given that it impacts on the question of what is a fair share of responsibility. For example, is GDP based on purchasing power parity ${ }^{204}$ per capita, which is certainly used

New Regionalism and Asylum Seekers: Challenges Ahead (Berghahn Books, 2007) 57.

203 For example, see the discussion of African states and local settlement in Chapter 5 .

204 Purchasing power parity refers to the amount of goods and services that a local currency can buy as compared with a stronger currency in its home country. 
by UNHCR when measuring states' contributions to refugee protection, ${ }^{205}$ the best indicator of capacity? Other interesting questions arise as to a) whether an 'internalist' 206 explanation of the causes of refugee flows, which defines the states from which refugees come as the most responsible, is always the most accurate and appropriate; b) whether viewing such states as responsible when non-state actors are involved is helpful; and c) whether involving such states necessarily leads to resolution of the root causes of refugee crises.

Before attempting to answer all these questions concerning regionalism and inter-regional cooperation, it is necessary to unpack another key concept - that of responsibility, for responsibility-sharing presumes agreement that refugees are people for whom responsibility should be taken by the international community. Responsibility can only be shared if all are agreed on the need for protection of refugees, wherever they may be. In Chapter 2 we look beyond the consensus reflected in treaties and customary international law and explore the deeper ethical concerns underpinning refugee protection.

205 See the tables attached to UNHCR's annual Global Trends publication for example, UNHCR, Global Trends 2013, above n 121.

206 Chimni, above n 108. 